\title{
Influence of the entrepreneur's capacity in business performance
}

\author{
Ricardo Teruel-Sánchez ${ }^{1}$ ( ) | Antonio Juan Briones-Peñalver ${ }^{2}$ () | \\ Juan Andrés Bernal-Conesa ${ }^{1}$ (ㄴ) | Carmen de Nieves-Nieto ${ }^{1}$ (
}

\author{
${ }^{1}$ Department of Economics and Juridical \\ Sciences (CUD-UPCT), University Centre of \\ Defence at the Spanish Air Force Academy, \\ San Javier, Spain \\ ${ }^{2}$ Department of Business Administration, \\ Technical University of Cartagena (UPCT), \\ Cartagena, Spain \\ Correspondence \\ Juan Andrés Bernal-Conesa, Department of \\ Economics and Juridical Sciences (CUD- \\ UPCT), University Centre of Defence at the \\ Spanish Air Force Academy. C/Coronel López \\ Peña s/n, 30720, San Javier, Spain. \\ Email: jandres.bernal@cud.upct.es
}

\begin{abstract}
The article presents a theoretical model of the entrepreneur's capacities and their influence on business performance. Starting from the traditional theory of dynamic capacities, those related to entrepreneurship and/or that influence the entrepreneur's capacities are identified, determining factors such as training, experience and confidence. In addition, other factors such as the environmental and institutional environment have been taken into account as they affect the entrepreneurship. For this purpose, a study was carried out with the Smart PLS software in a sample of companies in the tourism sector in the Mar Menor Region (Spain). An essential factor in the development of entrepreneurship in the region is the sustainability of the coastal lagoon. Some considerations are obtained from the study of the factors that determine the model of capacities, in which the confidence of the entrepreneur and the environmental sustainability, exert a positive and significant influence in the business performance. Furthermore, among the mentioned capacities of the entrepreneurial influence, experience and trust are the ones that most influence the success of the tourism business.
\end{abstract}

\section{KEYWORDS}

entrepreneur's capacity, institutional environment, Mar Menor Region, performance, structural equation modelling, sustainability

\section{1 | INTRODUCTION}

Entrepreneurial capacities are often characterized by conditions or entrepreneurship factors that affect their performance, as well as their economic well-being. The Resource and Capacity Theory highlights the relevance of resources and capacities as the basis for sustainable competitive advantages that guide organizational and strategic decisions of the enterprise. Resource-based view has emerged as an influential theoretical framework for understanding how competitive advantage is achieved through a complex collection of resources. However small firms have limited resources and investing in environmentally oriented business practices can be a costly and risky endeavor (Andersén et al., 2020).
Based on the efficient allocation of resources in order to maximize utility and profit functions the term entrepreneurship was coined by Richard Cantillon in his work "Essays on the Nature of Commerce in General," where he introduced the notion of the entrepreneur as an imperative variable of the economic system (Cantillon, 1950). Entrepreneurship has been studied from different perspectives since it will improve skills from a theoretical point of view (Chell, 2007), as it is a creative activity that achieves business benefits (Huerta de Soto, 2005). But it also means taking risks, experimenting and learning from mistakes (Foss \& Klein, 2012), being innovative in addressing business performance (Moloi \& Nkhahle-Rapita, 2014), having the ability to perceive opportunities by taking advantage of existing resources (Kwiatkowski, 2004) and being creative and proactive (Kedmenec et al., 2015). 
The local context influences entrepreneurship and it is extensively accepted that individual entrepreneurship and context are strongly related. Nevertheless, little is known about the impact of individual entrepreneurship on the entrepreneurial ecosystem (Martínez-Fierro, Biedma-Ferrer, \& Ruiz-Navarro, 2020). Moreover, the absence of a significant level of entrepreneurship, especially at the regional level, represents a deficit in sustainable development (Huggins \& Thompson, 2019).

Entrepreneurship becomes a complex phenomenon from a broad approach based on dynamic capabilities, in which factors of various types such as training, experience and confidence of business agents intervene and interact, both individually and collectively. The term dynamic capacity is part of a new approach in the field of strategic management (Jamil et al., 2019). This capacity was introduced by Teece et al. (1997) and defined as "the ability of the firm to integrate, build and reconfigure internal and external competencies to address rapidly changing environments where deep uncertainty exists" (Bogers et al., 2019). Other specialists consider dynamic capabilities as an extension of Resource and Capacity Theory in order to explain the sustainable competitive advantage of the firm (Zeng \& Mackay, 2018). This conforms to the theory of innovation (Schumpeter, 1934) which holds that organizations can achieve economic gains and attain competitive advantage by introducing successful innovations and innovatively managing their resources. This can be accompanied by a steady learning process and the seizing of new opportunities, acquiring knowledge from all reachable resources, and thus making appropriate decisions (Yunis et al., 2018).

Among the properties of the organizations that work under a competence model, it can be highlight their adaptation which can be identified as "dynamic capacities." This capacity identification is as important a strategic decision. It is as significant as decisions about which markets to enter, how to position oneself, in which markets exploit the existing resource positions, how to discourage entry and other "traditional" strategic variables (Pisano, 2017).

The higher degree of innovation complexity due to additional environmental requirements suggests that firms cooperate more intensively with stakeholders when it comes to environmentally beneficial innovations (Doluca et al., 2018). This theory is expanded with the introduction of knowledge, in which the company develops new capacities through dynamic learning capable of maintaining competitive advantages over time (Artal-Tur et al., 2019).

The theoretical contributions that recognize the positive benefits derived from dynamic capabilities are numerous, since those who focus on the development of new products and processes along with business model innovation will take advantage of them (Schoemaker et al., 2018).

Elia et al. (2020) show how competitive and cooperative dynamics can be virtuously integrated to provide individual (and company) driven responses to a timely socio-environmental issue. However, little attention has been paid to the role of the local context from a systemic approach, despite the fact that in recent years some empirical and theoretical studies have been carried out on the entrepreneurial ecosystem (Martínez-Fierro et al., 2020). Therefore, this sustainable entrepreneurship should be understand as a contribution to solving environmental and societal problems through the realization of a successful business and promoting sustainable development through entrepreneurial activities (Luedeke-Freund, 2020).

The main contribution to the literature of this article is to address, from the perspective of dynamic capabilities and local context, an under-explored topic such as the analysis of the individual entrepreneur's capacity, supported by acquired training, experience and self-confidence, and how all this influences business performance. In addition, to provide a definition of entrepreneurship based on the review and model of entrepreneurial capacities.

Therefore, questions such as whether training and experience are variables that constitute the entrepreneur's own confidence, or whether this confidence influences business performance and institutional environment, are analyzed.

In order to answer all these questions, this paper is structured as follows. First, it studies the impact of the entrepreneur's capacity (training, experience and confidence) on business performance, and investigates the mediation of other factors such as the institutional environment and environmental sustainability, which leads to the establishment of a series of hypotheses. Second, with the purpose to confirm them, an empirical study is carried out, developed in the tourism sector, specifically how this decision is configured in the Mar Menor Region in Spain.

\section{2 | LITERATURE REVIEW AND HYPOTHESES DEVELOPMENT}

The Region of Murcia has a physical geographical specificity, derived from natural conditions, the climate and the region that provide unique distinctive features, and shape its competitive advantage. The Mar Menor is a saltwater lagoon with an extension of $170 \mathrm{~km}^{2}$, about to 3 to $6 \mathrm{~m}$ deep and its total coastal perimeter is $70 \mathrm{~km}$. An old $20 \mathrm{~km}$ long chain of dunes, called "La Manga," separates it from the Mediterranean Sea. This area allows the communication of both seas through five natural channels, called "golas," currently expanded for maritime navigation (García-Ayllón, 2018).

In the region, the tourism sector, with a wide offer, which is not only limited to Sun and beach but can also deliver great possibilities in sports, health and beauty, gastronomic tourism, etc. This offer has not been exploited enough and has a wide range of improvement. The development of new products and experiences is essential for the growth of tourism entrepreneurship (Char-lee et al., 2020).

Following the recommendations for the development of sustainable tourism of the European Parliament, the characteristics of the destination, its environmental sustainability and the capacities of the entrepreneur will be the factors to be studied in this increase in entrepreneurship in the region (Weston et al., 2019).

An essential factor in the development of entrepreneurship in the region is the sustainability of the coastal lagoon. It is the fundamental element in the tourism model and which constitutes a fundamental component in the creation and development of small and medium- 
sized enterprises. In which a series of anthropogenic effects are given (urban settlements, intensive farming, mass tourism, industry, mining, fishing, ports, etc.), that along with discharges of diverse nature, recent floods, has produced an important leakage of organic matter and nutrients to the lagoon thus degrading the Mar Menor (Garcia-Ayllón, 2017). Given these offer characteristics, local politics needs to develop its own specific strategies to take advantage of the potential of entrepreneurship as a growth engine (Audretsch, 2018). The entrepreneur must define sustainable and environmentally friendly strategies that give more strength to the offer of this region.

The study of resources and capacities involves identifying the strengths of the company to take advantage of its talents against its competitors (Riveros et al., 2004). The importance of managing resources in order for them to generate superior performance has been stressed in numerous publications (Andersén et al., 2020). Chavez et al. (2020) explain that entrepreneurial individual orientation builds and strengthens internal practices for creating triple bottom line competitive advantage.

Intangible resources and capacities represent the foundations that would become solid advantages of the entrepreneurship, if used properly. These can include training, experience and confidence.

The intention to create a company is marked by motivations related to personal characteristics (internal) and environmental factors (external) (Degeorge \& Fayolle, 2011).

Theory suggests that members of family firms pursue the accumulation and conservation of wealth for future family generations and of the family name and thus its reputation, which has often been built up over several generations (Doluca et al., 2018). We find that family firms initially lag regarding environment-related activities, beneficial product, process and organizational innovations and performance.

Previous studies show that training and experience are determining factors in business performance (Agarwal et al., 2004). These can be constitutive of perception and feasibility of entrepreneurship, increasing it if the individual has close, even familiar, examples. This would lead us to situations where such actions can be carried out successfully (Dyer et al., 2014; Eddleston et al., 2008; Stam et al., 2014).

\section{1 | Training, experience and confidence in the entrepreneurship}

The most important resource available to the entrepreneur is the human factor (Marrero \& Moré, 2017). Their preparation and training are directly related to the future productivity of the company. This production factor does not depend so much on quantity as on quality, based on the degree of training, skills, abilities, and work experience that these people possess. The training and experience aspects make up a quantifiable value associated with each person that entails their assignment to a job and their level of remuneration (Chou et al., 2020; Lee et al., 2016).

Previous research has shown that training and experience have an exponential effect on the results and survival of companies (Headd, 2003; Simón-Moya et al., 2012). In this sense, we must understand the results and survival of the company as the business performance.

The probability of success of a new company will depend on entrepreneur capacities (Hopp \& Sonderegger, 2015). Among them, learning skills and acquired experience allow for the exploration of new knowledge and the development of new products (Yalcinkaya et al., 2007). These can also be considered features that are part of the entrepreneurial dynamic to achieve success in a business (Abdulwahab, 2015; Santos et al., 2018).

Teece's Dynamic Capabilities Model (2007) considers that these are competitive advantage, especially in changing environments, but not limited to business management. Nevertheless, also affecting other activities such as discovering business opportunities and how to deal with them. In this way, the entrepreneur's capacities are in a changing environment and must be adapted to this dynamism. This dynamism allows the entrepreneur to face threats of the market and explore the opportunities that arise from the environment, to implement sustainable businesses. The challenge for the entrepreneur is to capture this knowledge, which is the result of training and experience, and which feeds back into his or her dynamic capabilities (Felin \& Powell, 2016), allowing to respond appropriately to changes and to increase his or her confidence in businesses.

\subsection{1 | Training as entrepreneurship capacity}

Training is a key element in fostering entrepreneurial attitudes, intentions and skills (Maresch et al., 2016; Nabi et al., 2008). It facilitates relationships with stakeholders and improves project management (Fatma et al., 2020). This training becomes a good result if the dynamic capabilities model mediates business performance (Yáñez-Araque et al., 2017).

The education is essential to provide the skills and knowledge that are fundamental to the development of an entrepreneurial culture (Botha \& Bignotti, 2016), this is also one of the key elements to increase people's business attitudes (Potter, 2008). Botha and Bignotti (2017) postulate that people with higher levels of training and/or education are associated with a greater ability to understand information from the environment, guiding their objectives and their business idea more effectively.

In this sense, education associated with people's knowledge can provide a competitive advantage and become a potential for business sustainability. Both knowledge and sustainability are considered critical factors in achieving new business results (West \& Noel, 2009). Therefore, there is an important relationship between entrepreneur training as a capacity and the achievement of business performance (Faggian et al., 2017; Yáñez-Araque et al., 2017).

As a result of the above reasoning GEM Spain 2017-2018 provides a report which states that a key quality for entrepreneurship is that the person must believe that have sufficient knowledge and skills to undertake. The results of this study show that $81.3 \%$ people involved in entrepreneurship consider they have these qualities (Informe GEM España 2017-2018, 2018). Furthermore, Spain 2017 
GEM Report shows the distribution of total entrepreneurial activity by education level in 2017 a $49.8 \%$ of them reached higher or postgraduate education, while $50.2 \%$ reached secondary or primary education.

Training as an entrepreneurial capacity, requires not only learning how to manage a company but also having an impact on the skills and abilities needed to carry out the business activity (creativity, communication, confidence, risk taking, etc.). Such training is positively related to the identification of business opportunities (Olugbola, 2017).

Training, based on explicit knowledge about entrepreneurship positively influences the entrepreneur's confidence in their performance (Liñan \& Chen, 2009). Therefore, we can conclude with the following hypothesis.

Hypothesis 1a: Training contributes positively to entrepreneur confidence.

\subsection{2 | Experience as entrepreneurship capacity}

The experience allows a better identification, acquisition and exploitation of the resources that the new entrepreneur has available (Ribeiro \& Castrogiovanni, 2012), helps to identify opportunities that occur in similar situations (Shane, 2000). Experience plays a decisive role for entrepreneurs who decide to create a business seeking their own security or freedom (Shabbir \& di Gregorio, 1996).

When the experience becomes a routine, because its repetitive nature, it is a denoted capacity that results from the knowledge acquired over time and can have a positive moderating effect on the performance of new companies (Gompers et al., 2008; Kaplan \& Schoar, 2005; Mattingly et al., 2016; Sørensen, 2007). Duchek (2018) points out that the impact of experience on business management must have positive effects on entrepreneurs in order to recognize new business opportunities.

Entrepreneurs who already have previous experience can analyze previous results and his background experience, that provides them with greater chances of success in taking new risks, and also provides the necessary confidence to think about succeeding in their decision to act (Krueger \& Dickson, 1994), providing useful knowledge for the development of the new company (West \& Noel, 2009).

Knowledge and information acquired as a capacity through previous work experience facilitates the identification of employer opportunities (Shepherd \& Patzelt, 2010). This capacity is reinforced when they come from a family business, which provides a holistic knowledge of the problems that can be faced. And, it is reinforced with relationships with other entrepreneurs and the support of business associations resulting from business cooperation (St-Jean et al., 2017).

Personal and work experiences are part of their entrepreneurial capacity. Their lack of them can be considered a mayor limiting factor when deciding to create a new company and only a thorough training can alleviate this deficit (Botha \& Bignotti, 2016).
In this way, the entrepreneur analyzes all the information derived from his or her experience, comparing not only risks and benefits but also making a rational decision based on his or her perceived capacities and skills. This type of behavior gives confidence in decisionmaking (Mellalieu et al., 2006; Suarez \& Maldonado, 2018).

Therefore, we assume that previous experience affects the entrepreneur's confidence undertaking, so the following hypothesis can be proposed.

Hypothesis 1b: Experience positively influences the confidence of the entrepreneur.

\subsection{3 | Confidence as entrepreneurship capacity}

Confidence can be understood as the individual's perception of possessing enough knowledge and skills to start the entrepreneurship successfully. This knowledge is acquired throughout the learning and previous experience (Arenius \& Minniti, 2005; Axelrod, 2017; Kayemuddin, 2012).

It reflects the capacity that it believes to possess to develop competitive advantages in dynamic contexts (Jamil et al., 2019). These dynamic capacities suppose the entrepreneur's abilities to mold his skills to the environment fluctuations (Teece et al., 1997).

In this way, this confidence is the main force for develop the entrepreneurial intention (Miralles et al., 2016). However, confidence can lead to over-optimistic forecasts associated with the failure of companies; this factor is moderated by the educational level of the entrepreneur (Bernoster et al., 2018; Invernizzi et al., 2016).

Control of perceived behavior is correlated with confidence to perform an action; motivates the individual to make career or entrepreneurial decisions (Krueger et al., 2000). When the individual's confidence leads to perceive entrepreneurship as desirable and feasible, credibility in the project is generated. Such credibility leads to the start of a potential business. Belief in one's own capacities is related to business development and therefore to entrepreneurship (Porfírio et al., 2018). Business performance is an important component for the viability of new companies and relies heavily on both the judgment of the ability to succeed and the confidence of the entrepreneur to make the right decisions (García-Vidal et al., 2019; Ruvio et al., 2010). In our study, the relationship between entrepreneur confidence and performance could be assumed as follows:

Hypothesis 2: Entrepreneur confidence positively influences business performance.

\section{2 | Sustainability in the entrepreneurship}

Sustainability is a strength for the company, and is based on the idea of producing goods and services while preserving future capabilities (Lim et al., 2017). In this sense, it has been progressively introduced into strategic business management, taking into account factors such 
as the preservation of the environment, human rights and cohesion between human and social rights (Moneva \& Ortas, 2010).

The entrepreneur needs to achieve success ensuring his or her individual confidence, which becomes an indisputable factor of entrepreneurship. This has been considered and in turn influenced by the social and cultural aspects of the environment (McClelland, 1961). Demonstrating that this capacity of the entrepreneur, as a social way of recognition, plays an important role when owners trust in different stakeholders and companies relate to their business (Zhu et al., 2019).

Entrepreneurs must incorporate universal values such as responsibility, discipline, ethics, perseverance, exemplariness and transparency in their actions, which will allow them to develop an adequate level of trust and credibility in their social and environmental actions with their clients, suppliers, workers, and investors (Valenzuela Fernández et al., 2015).

Certain concepts such as sustainable development and social responsibility, which are demanded by stakeholders, must be presented from the beginning of the new company design (Gray et al., 2020; Wilburn \& Wilburn, 2011). Sustainable entrepreneurship seeks to implement business options, developed in a voluntary and responsible manner, that not only generate individual economic capacity and increased reputation, but simultaneously generate trust in society (Fischer et al., 2020).

The development of these capacities can help the incorporation of sustainability measures and social action (Redington, 2005), this implementation needs the commitment and motivation of the entrepreneur (Musibah \& Alfattani, 2013), giving a relation between the competences and the appearance of these sustainability measures (Razafindrambinina \& Kariodimedjo, 2011).

The entrepreneur's confidence in his/her performance capacities allows him/her to recognize the need to internalize environmental sustainability budgets as part of a long-term strategy, which gives him a differential argument against his competitors, therefore, we hypothesize that

Hypothesis 3a: Entrepreneur's confidence in his or her own capacities can favor environmental initiative.

Nowadays, environmental sustainability is no longer a philanthropic concept. But it can be considering a requirement for companies to be committed and visible in terms of the measures they are been taken to minimize the impact their actions generate (Rodríguez \& Ríos-Osorio, 2016).

Sustainable entrepreneurship is based on profit generation in the broadest sense of the term, i.e. including both economic gains to meet the needs of the entrepreneur and those of all the society (Shepherd \& Patzelt, 2010).

New companies must opt for a new management style in which the principle of shared value is considered, choosing those actions that benefit both the company and its different stakeholders (Moneva \& Ortas, 2009). Companies seek to integrate their economic objectives with environmental sustainability actions, so that benefits are achieved simultaneously for all stakeholders (Rashid et al., 2013).
These stakeholders must be considered by the entrepreneur to achieve their strategic objectives (García-Sánchez et al., 2018).

Environmental sustainability initiatives help to create an image and reputation in society, and therefore can lead to better levels of corporate profitability (Ferrero, 2013). Sustainable business models are sources of competitive advantage since the incorporation of sustainable value propositions generate economic benefits for companies, since they are identified as a potential factor in improving company performance (Porter \& Kramer, 2011; Rao \& Holt, 2005).

In this way, the impact of social responsibility and sustainability on organizational performance has been highlighted (GallardoVázquez \& Castilla-Polo, 2015; Reverte et al., 2016). It is therefore expected that sustainability measures will have a positive relationship with business performance, so the following hypothesis can be formulated:

Hypothesis 3b: Environmental sustainability contributes positively to business performance.

\section{3 | Institutional environment in the entrepreneurship}

Most public policies related to entrepreneurship do not solve market problems. However, these policies encourage people who are determined to engage in business activities even with a single employee. This type of business that has scarce motivation to innovate, consumes public resources that have a low and ineffective return (Acs et al., 2016).

For further entrepreneurship development it is necessary to improve certain structural elements for public organism, institutionalizing an environment where the capacity to take risks, innovation and initiative in organizational management are common structural elements in every organization (Gómez Haro \& Salmerón Gómez, 2011)

The quality of the institutional environment is an essential factor for economic growth. The European Quality of Government Index (EQI), created by the Institute for Quality in Government at the University of Gothenburg, is the only indicator of institutional quality available at regional level in the European Union. It aims to capture citizens' perceptions of corruption, the impartiality of public services and their quality.

Support from the institutional environment should promote a closer entrepreneur's behavior in accordance with social responsibility values and environmental protection, increasing their legitimacy and reputation (Yi, 2020). An adequate institutional environment, as far as entrepreneurship is concerned, will be that which makes it easier and/or cheaper for the new entrepreneur to start his business. In this sense, the institutional environment plays a key role in explaining entrepreneurial activity (Rodríguez-Gulías et al., 2020; Urbano et al., 2019), configured as a factor of vulnerability or development of the company's capabilities (Herbane, 2019). 
Therefore, a positive relationship between the institutional environment and business performance is assumed, which would lead to the following hypothesis.

Hypothesis 4: Closer institutional environment contributes to motivate business performance.

Figure 1 shows all the above hypotheses.

\section{3 | METHODOLOGY}

The objective of this empirical research is to explore the effect of the entrepreneur's capacities on the business performance. This section will explain in detail how the sample has been selected, the variables that have been constructed, the sources have been used, the method that have been used, as well as the statistical analysis performed.

\section{1 | Sample}

Tourism sector is a strategic sector for the economic dynamism of the Region, contributing to regional GDP with $11.4 \%$ of the regional total, growing above the whole economy. The Strategic Tourism Plan of Region of Murcia for the period 2015-2019, states that sun and beach tourism, characteristic of our region, is still the most important segment, producing $81 \%$ of the overnight stays in coastal accommodation. The constant improvement in the education and training of our tourism entrepreneurs is essential to raise quality, satisfaction and customer loyalty for the sake of greater competitiveness (Comunidad Autónoma de la Región de Murcia, 2019).

A determining factor in entrepreneurship development in the Mar Menor Region is the sustainability of the lagoon. This is not only an essential element in the tourism model but also a fundamental component in the creation and development of small and medium enterprises. Preventing the degradation of this ecosystem is vital for sustainable economic development. This economic growth must be combined with a rational use of natural resources. At this moment, the lagoon is suffering a serious environmental imbalance, due to significant contamination by nitrates and organic compounds, aggravated by the torrential rains that occurred in 2016 and the latest in 2019 and 2020, which has led to the adoption of urgent measures to ensure the environmental sustainability of its surroundings (Velasco et al., 2017).

Entrepreneurs to whom this study is addressed will be those dedicated to the following branches of activity related to the tourism sector: accommodation, catering, retail trade, travel agencies, tour operators and various services such as advertising, real estate services, sports, recreation and entertainment.

The population chosen for this study are Small and Medium Family Enterprises related to tourism sector in the Mar Menor Region. The family establishments that are most related to this sector due to their main activity were chosen. Thus, data was collected from the Statistical Portal of the Region of Murcia, these are referenced to the year 2014, and its last update date was April 4, 2019, for establishments whose main activity was: Retail, accommodation services, food and beverage services and other services, this section includes real estate activities, travel agencies, advertising agencies, sports, recreation, and entertainment. Table 1 below shows the number of establishments according to the activities defined above, by population of the region:

Table 2 shows technical data sheet.

\subsection{Analysis and results}

Statistical technique used for analyzing the proposed hypotheses was structural equation modelling (SEM) through Smart PLS 3.2.9 software. The technique used within SEM is known as PLS (Partial Least Squares).

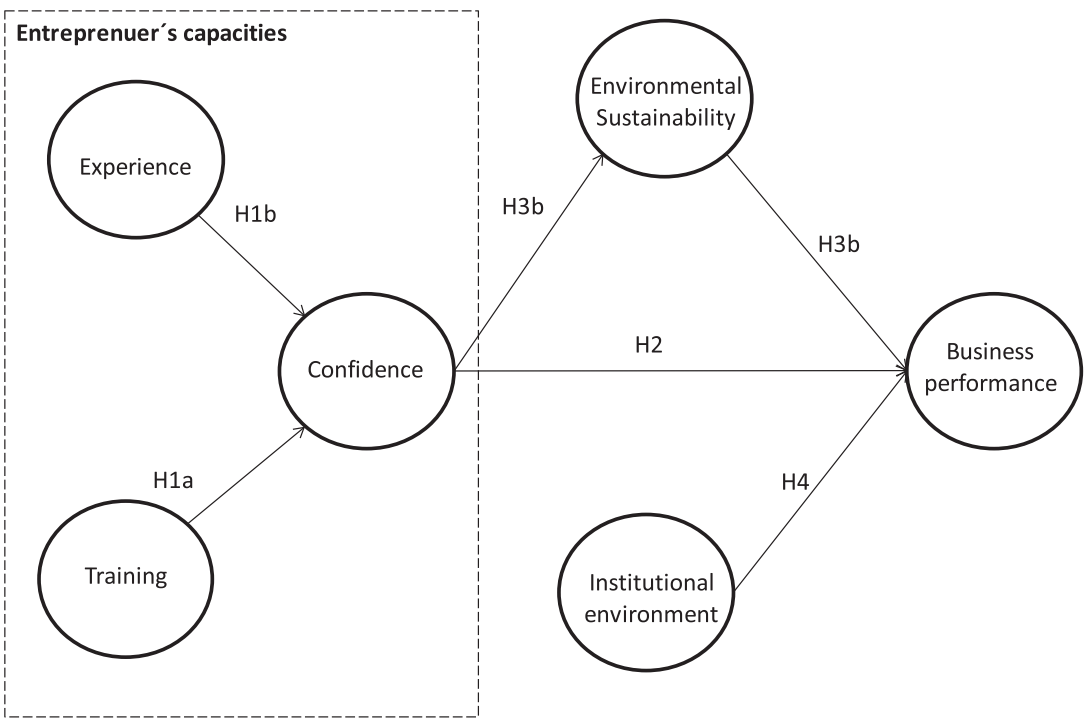

FIGURE 1 Conceptual model 
TABLE 1 Number of establishments by populations

\begin{tabular}{|llllrrr} 
& Retail & Accommodation services & Food and beverage services & Other services & Total \\
\hline San Javier & 544 & 38 & 386 & 188 & 1156 \\
\hline San Pedro del Pinatar & 354 & 14 & 243 & 107 & 718 \\
\hline Los Alcázares & 203 & 15 & 226 & 52 & 526 \\
\hline Torre Pacheco & 536 & 7 & 240 & 132 & Total \\
\hline
\end{tabular}

Note: Source: Authors.

TABLE 2 Technical sheet

\begin{tabular}{|ll|}
\hline Universe & $\mathbf{3 3 1 5}$ companies \\
\hline Geographical area & Mar Menor Region (Murcia) \\
\hline Method of information collection & On-line survey \\
\hline Population census & 525 contacted companies \\
\hline Sample size & 120 companies \\
\hline Participation rate & 22.85 \\
\hline Sampling error & 7.86 \\
\hline Level of confidence & $95 \% ; z=1.96 ; p=q 0.5$ \\
\hline Sample method & Not random convenience \\
\hline Date of fieldwork & 2019 May-December \\
\hline
\end{tabular}

Source: Authors.

PLS-SEM is acceptable for numerous situations of research, such as family business (Sarstedt et al., 2014) information systems (Hair, Hollingsworth et al., 2017), and tourism (Artal-Tur et al., 2019). PLSSEM is used for assessing the theoric model because is based on an iterative algorithm to obtain weights used for building linear combinations of observed indicators for all latent variables which facilitates the measurement of hypotheses to be verified (Müller et al., 2018).

A SEM really consists of both a measurement (outer) model and a structural (inner) model. The pattern of association between latent variables and their indicators is investigated by the measurement model, and the relationships between these variables (construct) are studied by structural model (Hair et al., 2014).

As none of the variables considered with respect to the established hypotheses is directly observable, indicators were used to reflect the constructs (Table 3 ) based on the literature consulted. Five-point Likert measurement scales were defined in a questionnaire, to approximate their values, formed by various indicators that collect the perceptions of the managers of the firms consulted in line with other studies (Bernal-Conesa et al., 2017).

\subsection{1 | Outer model}

Convergent validity and reliability of the reflective constructs is evaluated by the Dijkstra and Henseler's rho $\left(\rho_{A}\right)$, average variance extracted (AVE), factor loading values and level of significance (Dijkstra \& Henseler, 2015). Individual item reliability is assessed by simple correlations of indicators with their latent variable and the standardized loadings ( $\lambda$ ) (Hair, Hult et al., 2017).

Loadings $(\lambda)$ greater than 0.7 are accepted thus the indicators will be part of their corresponding constructs (Table 3). Cronbach's $\alpha, \rho_{\mathrm{A}}$, and $\rho_{c}$ must be greater than 0.707 and AVE must be greater than 0.5 . The discriminant validity of the constructs is also assessed using the HTMT (heterotraot-monotrait) (Müller et al., 2018). According to this criterion, a construct has discriminant validity when the HTMT correlation ratio is below the value of 0.85 (Henseler et al., 2015). In this case, all HTMT relationships present values below that threshold (Table 4). As a result, the model shows a good performance in terms of reliability, convergent validity, and discriminant validity of the constructs.

\subsection{2 | Inner model}

Model quality assessment is based on standardized path coefficients $(\beta)$ with confidence intervals and SRMR (Standardized Root Mean Square Residual). The outcome for the inner model is provided by the bootstrap method of PLS-SEM. $\beta$ s above 0.2 are desirable, while $\beta$ is also expected to be significant when it does not show a zero value in its confidence interval (Sarstedt et al., 2017). See Figure 2.

\subsection{3 | Goodness of fit}

An acceptable overall model fit is essential in order to understanding the parameter estimates because it shows whether the underlying theory is echoed in the data (Müller et al., 2018).

The value of SRMR must be less than 0.10 for PLS-SEM (Hair, Hult, et al., 2017) for the measurement model and the structural model, and values around and below their confidence intervals. The measurement model is compared to the structural model in order to obtain empirical evidence on whether the estimated model fits the collected data. In addition to the SRMR, the geodesic distance (dG) and the Euclidean distance (dULS) are calculated (Table 5).

The model is accepted if obtained values are smaller than the quantile of the confidence intervals. Hence, our model has to be accepted and theory is reflected in the data.

It should be noted that the confidence of the entrepreneur has a high influence on performance and also this relationship is reinforced 
TABLE 3 Indicators, loadings $(\lambda)$, and measurement model assessment

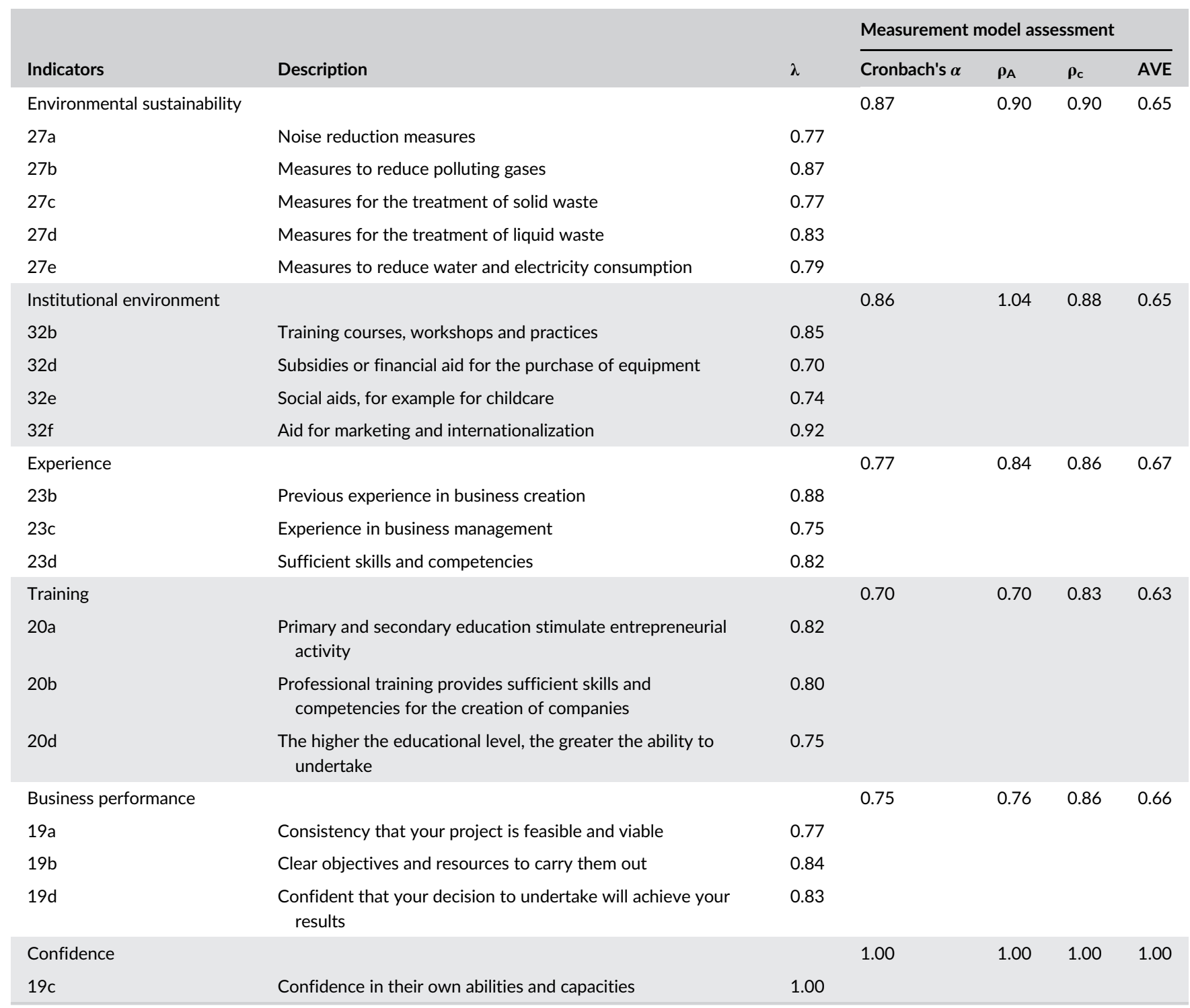

Source: Authors.

by environmental sustainability (Table 6). And within capacities, experience and confidence are the most influential and statistically significant; however, training is not relevant for business performance or for employer confidence.

\section{4 | DISCUSSION AND CONCLUSION}

The aim of this empirical study tries to deep on the effects of the entrepreneur's capacities on their business performance, studying how features treated can affect company's success particularly in small companies located in the Mar Menor Region in Spain.

The analysis has focused on two aspects: internal and external. The internal ones consider those that affect the entrepreneur (training, experience, and confidence) while the external ones understand (environmental sustainability and institutional environment).

\section{1 | Theoretical contribution}

Based on what is exposed in the work, entrepreneurship can be defined as "the irruption of human action in the market, in the way that the entrepreneur, with capacities and information, discovers in himself/herself new and value-creating ideas, achieving benefits where others do not obtain them, affecting employment and economic growth."

In this way, economic can be considered as a determining factor in the establishment of a new company. However, many people are willing to sacrifice income in exchange of other types of nonpecuniary benefits (Hamilton, 2000). Economic motivation may dominate in the early stages of project development, when other objectives are often sacrificed in favor of the former. However, in later phases, other motivations play a more important role, from the need to make one's own decisions, to the possibility of using one's 
TABLE 4 Discriminant validity analysis and $\mathrm{HTMT}$ values

\begin{tabular}{|lllllll|}
\hline & X1 & X2 & X3 & X4 & X5 & X6 \\
\hline Sustainability (X1) & 0.81 & & & & & \\
\hline Confidence(X2) & 0.23 & 1.00 & & & & \\
\hline Business performance(X3) & 0.31 & 0.54 & 0.81 & & & \\
\hline Institutional environment (X4) & 0.11 & -0.17 & 0.08 & 0.81 & & \\
\hline Experience (X5) & 0.28 & 0.25 & 0.43 & 0.07 & 0.82 & \\
\hline Training (X6) & 0.28 & 0.10 & 0.35 & 0.34 & 0.25 & 0.79 \\
\hline HTMT values & & & & & & \\
\hline Sustainability (X1) & X1 & X2 & X3 & X4 & X5 & X6 \\
\hline Confidence(X2) & & & & & & \\
\hline Business performance(X3) & 0.22 & & & & & \\
\hline Institutional environment (X4) & 0.37 & 0.62 & & & & \\
\hline Experience (X5) & 0.35 & 0.25 & 0.55 & 0.11 & & \\
\hline Training (X6) & 0.37 & 0.12 & 0.49 & 0.40 & 0.36 & \\
\hline
\end{tabular}

Note: Diagonal elements (bold) are the square root of the variance shared between the constructs and their measures (average variance extracted). Off-diagonal elements are the correlations among constructs. For discriminant validity, diagonal elements should be larger than off-diagonal elements.

FIGURE 2 Hypotheses test

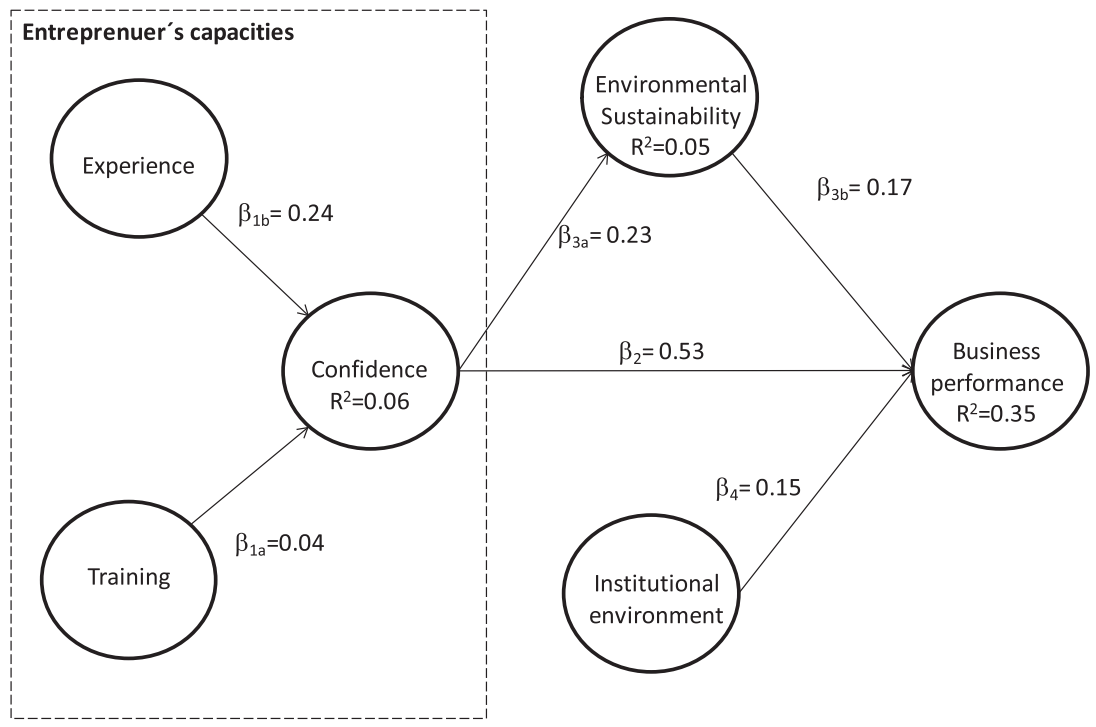

TABLE 5 Goodness of fit of the model

\begin{tabular}{|c|c|c|c|c|c|c|}
\hline & \multicolumn{3}{|c|}{ Measurement model } & \multicolumn{3}{|c|}{ Structural model } \\
\hline SRMR & 0.08 & 0.15 & 0.18 & 0.10 & 0.13 & 0.16 \\
\hline dULS & 1.29 & 4.29 & 5.84 & 2.93 & 3.40 & 4.84 \\
\hline
\end{tabular}

own time and the contribution to family welfare (Manolova, Brush, \& Edelman , 2008).

The results confirm that the entrepreneur's capacities influence business performance. The literature provided shows that the characteristics of the entrepreneur lead to increased capacity, which managing business performance (Sarwoko et al., 2013). The essence of entrepreneurship lies in the entrepreneur capacities (Grillitsch, 2019). 
TABLE 6 Total effects in the model

\begin{tabular}{|c|c|c|c|c|c|}
\hline \multicolumn{6}{|l|}{ Total effects } \\
\hline Environmental sustainability- > business performance & 0.17 & 2.03 & 0.04 & 0.02 & 0.35 \\
\hline Confidence- > environmental sustainability & 0.23 & 2.38 & 0.02 & 0.05 & 0.43 \\
\hline Confidence- $>$ business performance & 0.57 & 6.63 & 0.00 & 0.37 & 0.71 \\
\hline Institutional environment- > business performance & 0.15 & 1.25 & 0.21 & -0.14 & 0.33 \\
\hline Experience- > confidence & 0.24 & 2.95 & 0.00 & 0.11 & 0.40 \\
\hline Experience- > business performance & 0.14 & 2.58 & 0.01 & 0.05 & 0.25 \\
\hline Training- > environmental sustainability & 0.01 & 0.30 & 0.77 & -0.05 & 0.08 \\
\hline Training- > confidence & 0.04 & 0.34 & 0.74 & -0.22 & 0.25 \\
\hline
\end{tabular}

The results of the study show that training is not significant and only explains a small part of the entrepreneur's confidence and performance. This is against other studies that consider training as a resource that contributes positively to business performance (Aguinis \& Kraiger, 2009; Tharenou et al., 2007). Although is not clear how this training translates into improved business performance, some studies show weak results and even evidence of a negative relationship (Barba Aragón et al., 2014; Yáñez-Araque et al., 2017).

The results also confirm a lack of specific training for employers and workers in this sector, which is characterized by temporary contracts with low qualification requirements. The lack of regulated training in the tourism sector has not reached the training cycles in tourism until relatively recently, which has made the employer of this sector generally self-taught. Consequently, the entrepreneur influence of this variable on the confidence and performance is low.

On the contrary, experience especially in restaurants can compensate the shortcomings in regulated education with greater work experience (Hopp \& Sonderegger, 2015). Our results show that experience significantly affects the confidence of the entrepreneur, and also the business performance. Moreover, the motivation of employees to train and develop their productivity must be increased (Salehzadeh et al., 2017).

\section{2 | Practical implication}

On the other hand, empirical results confirm that confidence has a positive effect on business performance, being one of the entrepreneurship's dimensions, confirming what Javan (2014) established for small businesses. Likewise, our positive result is on line with other previous studies (Bondima et al., 2013; Laguador, 2013). With reference to training, the results obtained corroborate that it is not a determining factor for becoming an entrepreneur, as the study points out (Informe GEM España 2017-2018, 2018).

On the other hand, environmental responsibility reinforces business performance, since it is a factor that not only adds value but also is identified as a competitive advantage for a tourist destination. The strategy of focusing on customers and their needs has shown positive results in terms of performance in development of new tourism products (Yang \& Zhang, 2018). Therefore, this environmental dimension significantly affects the performance (Omidi \& Shafiee, 2018).

Many coastal areas are fragile, and recent decades have shown that tourism activities, particularly mass tourism, can threaten local ecosystems, and attractiveness of these areas (García-Ayllón, 2015).

This study has been carried out at a time the Mar Menor is being degraded both by urban development and by the environmental situation caused by the excess of nutrients dumped into the sea by intensive agriculture. This could lead to major changes in the lagoon, both at the ecological and environmental level and therefore their effects on socio-economic activities (Martínez-Fernández \& EstevaSelma, 2007). Thus, the regional government should promote policies that favor activity, such as urban planning, financial and fiscal incentives, in line with the importance of the tourism sector as the driving force of the regional economy.

Activities implemented in environmental responsibility policies should have a positive influence on the image and reputation of business (Nyarku \& Ayekple, 2019). The Business Environment is strictly related to the socio-economic development of the region (Bartkowiak-Bakun, 2017). Therefore, the entrepreneur must direct his capacities toward sustainable tourism activities that support this line of socio-economic development.

Both the present study and previous ones have studied the moderating effects between environment and business performance. The hypotheses studied show the moderating effect of the institutional environment, as higher levels of success in business performance are associated with higher capacities in dynamic environments mainly (Hazlina Ahmad et al., 2010).

Business conditions, especially at the regional level, are strictly related to the socio-economic development of the region (Bartkowiak-Bakun, 2017). Regional government should promote tourism policies based on the Spain brand, through urban, financial and fiscal incentives, in accordance with the importance of the tourism sector as the driving strength of the regional economy. 
The characteristics of the regional entrepreneurial ecosystem must be taken into account for the adoption of measures to support entrepreneurship (Szerb et al., 2019).

The effects of the COVID 19 pandemic on regional economies based primarily on the tourism sector make the implementation of these policies increasingly necessary, since higher levels of entrepreneurship reduce the impacts of crises (Williams \& Vorley, 2014). Moreover, some studies discuss the role of entrepreneurship in rebuilding local economies in order to become more resilient (Korsgaard et al., 2020).

\section{3 $\quad$ Limitations and future directions}

Although this work presents certain limitations associated with both geographical area and number of target cases. Thus, the study could be developed in other geographical areas in order to contrast the results and avoid the bias of cultural and socioeconomic factors. In addition, the information obtained in the surveys comes from owners and managers, so in future studies it is proposed to extend the range to other job positions.

While there is little empirical research on entrepreneurial skills, it should be further explored whether these are universal (Mitchelmore \& Rowley, 2010).

Based on the results of this work, new possibilities are opened to extend the study in several ways, one of which could be based on other demographic factors of employers, such as gender differences.

\section{ORCID}

Ricardo Teruel-Sánchez (D) https://orcid.org/0000-0002-1725-730X Antonio Juan Briones-Peñalver (D) https://orcid.org/0000-0002-2893$007 X$

Juan Andrés Bernal-Conesa (D) https://orcid.org/0000-0003-46264805

Carmen de Nieves-Nieto (D) https://orcid.org/0000-0001-9142-1908

\section{REFERENCES}

Abdulwahab, M. H. (2015). The impact of entrepreneurs' characteristics on small business success at medical instruments supplies organizations in Jordan. 6(8), 12.

Acs, Z., Åstebro, T., Audretsch, D., \& Robinson, D. T. (2016). Public policy to promote entrepreneurship: A call to arms. Small Business Economics, 47(1), 35-51. https://doi.org/10.1007/s11187-0169712-2

Agarwal, R., Echambadi, R., Franco, A., \& Sarkar, M. (2004). Knowledge transfer through inheritance: Spin-out generation, development, and survival. Academy of Management Journal, 47(4), 501-522. https://doi. org/10.5465/20159599

Aguinis, H., \& Kraiger, K. (2009). Benefits of training and development for individuals and teams, organizations, and society. Annual Review of Psychology, 60(1), 451-474. https://doi.org/10.1146/annurev.psych. 60.110707.163505

Andersén, J., Jansson, C., \& Ljungkvist, T. (2020). Can environmentally oriented CEOs and environmentally friendly suppliers boost the growth of small firms? Business Strategy and the Environment, 29(2), 325-334. https://doi.org/10.1002/bse.2366
Arenius, P., \& Minniti, M. (2005). Perceptual variables and nascent entrepreneurship. Small Business Economics, 24(3), 233-247. https://doi. org/10.1007/s11187-005-1984-x

Artal-Tur, A., Briones-Peñalver, A. J., Bernal-Conesa, J. A., \& Martínez-Salgado, O. (2019). Rural community tourism and sustainable advantages in Nicaragua. International Journal of Contemporary Hospitality Management, 31(6), 2232-2252. https://doi.org/10.1108/ IJCHM-05-2018-0429

Audretsch, D. (2018). Entrepreneurship, economic growth, and geography. Oxford Review of Economic Policy, 34(4), 637-651. https://doi.org/10. 1093/oxrep/gry011

Axelrod, R. H. (2017). In S. Dhiman (Ed.), Leadership Today. Springer Texts in Business and EconomicsLeadership and self-confidence. Cham: Springer. DOI: 10.1007/978-3-319-31036-7_17

Barba Aragón, M. I., Jiménez Jiménez, D., \& Sanz Valle, R. (2014). Training and performance: The mediating role of organizational learning. $B R Q$ Business Research Quarterly, 17(3), 161-173. https://doi.org/10.1016/ j.cede.2013.05.003

Bartkowiak-Bakun, N. (2017). The diversity of socioeconomic development of rural areas in Poland in the western borderland and the problem of post-state farm localities. Oeconomia Copernicana, 8(3), 417-432.

Bernal-Conesa, J. A., de Nieves Nieto, C., \& Briones-Peñalver, A. J. (2017). CSR strategy in technology companies: Its influence on performance, competitiveness and sustainability. Corporate Social Responsibility and Environmental Management, 24(2), 96-107. https://doi.org/10.1002/ csr.1393

Bernoster, I., Rietveld, C., Thurik, A., \& Torrès, O. (2018). Overconfidence, optimism and entrepreneurship. Sustainability, 10(7), 2233. https://doi. org/10.3390/su10072233

Bogers, M., Chesbrough, H., Heaton, S., \& Teece, D. J. (2019). Strategic management of open innovation: A dynamic capabilities perspective. California Management Review, 62(1), 77-94. https://doi.org/10.1177/ 0008125619885150

Bondima, C. E., Rankhumise, E., \& Grundling, J. (2013). Co-effect of culture and personality traits on business success of South African entrepreneurs. In The Global Business and Technology Association (pp. 102-111). Helsinki, Finland: Readings Book.

Botha, M., \& Bignotti, A. (2016). Internships enhancing entrepreneurial intent and self-efficacy: Investigating tertiary-level entrepreneurship education programmes. The Southern African Journal of Entrepreneurship and Small Business Management, 8(1), 1-15.

Botha, M., \& Bignotti, A. (2017). Exploring moderators in the relationship between cognitive adaptability and entrepreneurial intention: Findings from South Africa. International Entrepreneurship and Management Journal, 13(4), 1069-1095. https://doi.org/10.1007/s11365-0170437-8

Cantillon, R. (1950). Ensayo sobre la naturaleza del comercio en general. Londres: Fondo de Cultura Económica.

Char-lee, M., Brent, M., \& Henri, B. (2020). Entrepreneurial strategies and tourism industry growth. Tourism Management Perspectives, 35, 100708. https://doi.org/10.1016/j.tmp.2020.100708

Chavez, R., Yu, W., Sadiq Jajja, M. S., Lecuna, A., \& Fynes, B. (2020). Can entrepreneurial orientation improve sustainable development through leveraging internal lean practices? Business Strategy and the Environment, 29(6), 2211-2225. https://doi.org/10.1002/bse.2496

Chell, E. (2007). Social enterprise and entrepreneurship: Towards a convergent theory of the entrepreneurial process. International Small Business Journal, 25(1), 5-26. https://doi.org/10.1177/0266242607071779

Chou, S.-F., Horng, J.-S., Liu, C.-H., Huang, Y.-C., \& Zhang, S.-N. (2020). The critical criteria for innovation entrepreneurship of restaurants: Considering the interrelationship effect of human capital and competitive strategy a case study in Taiwan. Journal of Hospitality and Tourism Management, 42, 222-234. https://doi.org/10.1016/j.jhtm.2020. 01.006 
Comunidad Autónoma de la Región de Murcia. (2019). Plan estratégico turístico de la Región de Murcia 2015-2019. Estrategia Y Plan de Acción 2019.

de Soto, H. (2005). Socialismo, Cálculo ecómico y función empresarial (Tercera Edición). Sao Paulo, Brazil: Unión Editorial.

Degeorge, J., \& Fayolle, A. (2011). The entrepreneurial process trigger: A modelling attempt in the French context. Journal of Small Business and Enterprise Development, 18(2), 251-277. https://doi.org/10.1108/ 14626001111127061

Dijkstra, T. K., \& Henseler, J. (2015). Consistent partial least squares path modeling. MIS Quarterly= Management Information Systems Quarterly, 39(2), 297-316. https://doi.org/10.25300/MISQ/2015/39.2.02

Doluca, H., Wagner, M., \& Block, J. (2018). Sustainability and environmental behaviour in family firms: A longitudinal analysis of environmentrelated activities, innovation and performance. Business Strategy and the Environment, 27(1), 152-172. https://doi.org/10.1002/bse.1998

Duchek, S. (2018). Entrepreneurial resilience: A biographical analysis of successful entrepreneurs. International Entrepreneurship and Management Journal, 14(2), 429-455. https://doi.org/10.1007/s11365-0170467-2

Dyer, W. G., Nenque, E., \& Hill, E. J. (2014). Toward a theory of family capital and entrepreneurship: Antecedents and outcomes. Journal of Small Business Management, 52(2), 266-285. https://doi.org/10.1111/jsbm. 12097

Eddleston, K. A., Kellermanns, F. W., \& Sarathy, R. (2008). Resource configuration in family firms: Linking resources, strategic planning and technological opportunities to performance. Journal of Management Studies, 45(1), 26-50.

Elia, G., Margherita, A., \& Petti, C. (2020). Building responses to sustainable development challenges: A multistakeholder collaboration framework and application to climate change. Business Strategy and the Environment, 29(6), 2465-2478. https://doi.org/10.1002/bse.2514

Faggian, A., Partridge, M., \& Malecki, E. J. (2017). Creating an environment for economic growth: Creativity, entrepreneurship or human capital? International Journal of Urban and Regional Research, 41(6), 997-1009. https://doi.org/10.1111/1468-2427.12555

Fatma, E. B., Mohamed, E. B., Dana, L.-P., \& Boudabbous, S. (2020). Does entrepreneurs' psychology affect their business venture success? Empirical Findings from North Africa. International Entrepreneurship and Management Journal.. https://doi.org/10.1007/s11365-020-00644-3

Felin, T., \& Powell, T. C. (2016). Designing organizations for dynamic capabilities. California Management Review, 58(4), 78-96. https://doi.org/ 10.1525/cmr.2016.58.4.78

Ferrero, Y. (2013). Consecuencias de las prácticas de sostenibilidad en el coste de capital y en la reputación corporativa. Spanish Accounting Review, 17(2), 153-162. https://doi.org/10.1016/j.rcsar.2013.08.008

Fischer, D., Brettel, M., \& Mauer, R. (2020). The three dimensions of sustainability: A delicate balancing act for entrepreneurs made more complex by stakeholder expectations. Journal of Business Ethics, 163(1), 87-106. https://doi.org/10.1007/s10551-018-4012-1

Foss, N. J., \& Klein, P. G. (2012). Organizing entrepreneurial judgment: A new approach to the firm. The Pitt Building, Trumpington ST, Cambridge CB2 1RP, Cambs, England: Cambridge Univ Press. https://doi.org/10. 1017/CBO9781139021173

Gallardo-Vázquez, D., \& Castilla-Polo, F. (2015). Responsabilidad social corporativa y capital intelectual en las organizaciones. Congreso AECA 2015.

García-Ayllón, S. (2015). La Manga case study: Consequences from shortterm urban planning in a tourism mass destiny of Spanish Mediterranean coast. Cities, 43, 141-151. https://doi.org/10.1016/j.cities.2014. 12.001

García-Ayllón, S. (2017). Integrated management in coastal lagoons of highly complexity environments: Resilience comparative analysis for three case-studies. Ocean and Coastal Management, 143, 16-25. https://doi.org/10.1016/j.ocecoaman.2016.10.007
García-Ayllón, S. (2018). GIS assessment of mass tourism anthropization in sensitive coastal environments: Application to a case study in the Mar Menor Area. Sustainability, 10, 1-7. https://doi.org/10.3390/ su10051344

García-Sánchez, E., García-Morales, V. J., \& Martín-Rojas, R. (2018). Analysis of the influence of the environment, stakeholder integration capability, absorptive capacity, and technological skills on organizational performance through corporate entrepreneurship. International Entrepreneurship and Management Journal, 14(2), 345-377. https://doi.org/ 10.1007/s11365-017-0436-9

García-Vidal, G., Sánchez-Rodríguez, A., Pérez-Campdesuñer, R., \& Martínez-Vivar, R. (2019). The impact of self-confidence, creativity and vision on leadership performance: Perceptions at Ecuadorian SMEs owner-managers. Serbian Journal of Management, 14(2), 315-325. https://doi.org/10.5937/sjm14-17569

Gómez Haro, S., \& Salmerón Gómez, R. (2011). Influencia del entorno institucional en el desarrollo del emprendimiento español. Un análisis empírico. Revista Venezolana de Gerencia, 54, 191-208.

Gompers, P., Kovner, A., Lerner, J., \& Scharfstein, D. (2008). Venture capital investment cycles: The impact of public markets. Journal of Financial Economics, 87, 1-23.

Gray, S. G., Sütterlin, B., Siegrist, M., \& Árvai, J. (2020). The benefit of virtue signaling: Corporate sleight-of-hand positively influences consumers' judgments about "social license to operate". Journal of Environmental Management, 260, 110047. https://doi.org/10.1016/j. jenvman.2019.110047

Grillitsch, M. (2019). Following or breaking regional development paths: On the role and capability of the innovative entrepreneur. Regional Studies, 53(5), 681-691. https://doi.org/10.1080/00343404.2018. 1463436

Hair, J., Hollingsworth, C. L., Randolph, A. B., \& Chong, A. Y. L. (2017). An updated and expanded assessment of PLS-SEM in information systems research. Industrial Management \& Data Systems, 117(3), 442-458. https://doi.org/10.1108/IMDS-04-2016-0130

Hair, J. F., Hult, G. T. M., Ringle, C., \& Sarstedt, M. (2017). A primer on partial least squares structural equation modeling (PLS-SEM) (2nd ed.). Thousand Oaks, California 91320: SAGE Publications.

Hair, J. F., Sarstedt, M., Hopkins, L., \& Kuppelwieser, V. G. (2014). Partial least squares structural equation modeling (PLS-SEM): An emerging tool in business research. European Business Review, 26(2), 106-121. https://doi.org/10.1108/EBR-10-2013-0128

Hamilton, B. H. (2000). Does entrepreneurship pay? An empirical analysis of the returns to self-employment. Journal of Political Economy, 108(3), 604-631. https://doi.org/10.1086/262131

Hazlina Ahmad, N., Ramayah, T., Wilson, C., \& Kummerow, L. (2010). Is entrepreneurial competency and business success relationship contingent upon business environment?: A study of Malaysian SMEs. International Journal of Entrepreneurial Behavior \& Research, 16(3), 182-203. https://doi.org/10.1108/13552551011042780

Headd, B. (2003). Redefining business success: Distinguishing between closure and failure. Small Business Economics, 21(1), 51-61. https://doi. org/10.1023/A:1024433630958

Henseler, J., Ringle, C. M., \& Sarstedt, M. (2015). A new criterion for assessing discriminant validity in variance-based structural equation modeling. Journal of the Academy of Marketing Science, 43(1), 115-135. https://doi.org/10.1007/s11747-014-0403-8

Herbane, B. (2019). Rethinking organizational resilience and strategic renewal in SMEs. Entrepreneurship and Regional Development, 31(5-6), 476-495. https://doi.org/10.1080/08985626.2018.1541594

Hopp, C., \& Sonderegger, R. (2015). Understanding the dynamics of nascent entrepreneurship-Prestart-up experience, intentions, and entrepreneurial success. Journal of Small Business Management, 53(4), 1076-1096. https://doi.org/10.1111/jsbm.12107

Huggins, R., \& Thompson, P. (2019). Human agency, entrepreneurship and regional development: A behavioural perspective on economic 
evolution and innovative transformation. Entrepreneurship and Regional Development, 32, 1-17. https://doi.org/10.1080/08985626.2019. 1687758

Informe GEM España 2017-2018. (2018). Centro Internacional Santander Emprendimiento. http://www.gem-spain.com/wp-content/uploads/ 2018/09/PDF-17-1695-9302.pdf

Invernizzi, A. C., Menozzi, A., Passarani, D. A., Patton, D., \& Viglia, G. (2016). Entrepreneurial overconfidence and its impact upon performance. International Small Business Journal, 35(6), 709-728. https:// doi.org/10.1177/0266242616678445

Jamil, G. L., Jamil, L. C., Pessoa, C. R. M., \& Silveira, W. (2019). Handbook of research on business models in modern competitive scenarios. Brazil: IGI Global. www.igi-global.com/book/handbookresearch-business-models-modern/205239, https://doi.org/10.4018/ 978-1-5225-7265-7

Javan, R. S. (2014). The relationship between personality traits and entrepreneurial intentions. Social and Management Research Journal, 11(2), 46. https://doi.org/10.24191/smrj.v11i2.5239

Kaplan, S. N., \& Schoar, A. (2005). Private equity performance: Returns, persistence, and capital flows. The Journal of Finance, 60(4), 1791-1823. https://doi.org/10.1111/j.1540-6261.2005.00780.x

Kayemuddin, M. D. (2012). Leadership in small business in Bangladesh. International Journal of Entrepreneurship, 16, 25-35.

Kedmenec, I., Rebernik, M., \& Peric, J. (2015). The impact of individual characteristics on intentions to pursue social entrepreneurship. Ekonomski Pregled, 66(2), 119-137.

Korsgaard, S., Hunt, R. A., Townsend, D. M., \& Ingstrup, M. B. (2020). COVID-19 and the importance of space in entrepreneurship research and policy. International Small Business Journal: Researching Entrepreneurship, 38(8), 697-710. https://doi.org/10.1177/ 0266242620963942

Krueger, J. N., \& Dickson, P. (1994). How believing in ourselves incresases risk-taking: Perceived self-efficacy and opportunity recognition. Decision Sciences, 25(3), 385-400. https://doi.org/10.1111/j.15405915.1994.tb01849.x

Krueger, N. F., Relly, M. D., \& Carsrud, A. L. (2000). Competing models of entrepreneurial intentions. Journal of Business Venturing, 15(5-6), 411-432. https://doi.org/10.1016/s0883-9026(98)00033-0

Kwiatkowski, S. (2004). Social and intellectual dimensions of entrepreneurship. Higher Education in Europe, 29(2), 205-220. https://doi.org/10. 1080/0379772042000234848

Laguador, J. M. (2013). A correlation study of personal entrepreneurial competency and the academic performance in operations management of business administration studentes. International Journal of Academic Research in Business and Social Sciences, 3(5), 61-70.

Lee, C., Hallak, R., \& Sardeshmukh, S. R. (2016). Innovation, entrepreneurship, and restaurant performance: A higher-order structural model. Tourism Management, 53, 215-228. https://doi.org/10.1016/j. tourman.2015.09.017

Lim, M. K., Tseng, M.-L., Tan, K. H., \& Bui, T. D. (2017). Knowledge management in sustainable supply chain management: Improving performance through an interpretive structural modelling approach. Journal of Cleaner Production, 162, 806-816. https://doi.org/10.1016/j. jclepro.2017.06.056

Liñan, F., \& Chen, Y. (2009). Development and cross-cultural application of a specific instrument to measure entrepreneurial intentions. Entrepreneurship Theory and Practice, 33, 593-618. https://doi.org/10.1111/j. 1540-6520.2009.00318.x

Luedeke-Freund, F. (2020). Sustainable entrepreneurship, innovation, and business models: Integrative framework and propositions for future research. Business Strategy and the Environment, 29(2), 665-681. https://doi.org/10.1002/bse.2396

Manolova, T., Brush, C., \& Edelman, L. (2008). What do women entrepreneurs want? Strategic Change, 17(3-4), 69-82. https://doi.org/10. $1002 /$ jsc. 817
Maresch, D., Harms, R., Kailer, N., \& Wimmer-Wurm, B. (2016). The impact of entrepreneurship education on the entrepreneurial intention of students in science and engineering versus business studies university programs. Technological Forecasting and Social Change, 104, 172-179. https://doi.org/10.1016/j.techfore.2015.11.006

Marrero, B., \& Moré, I. A. (2017). Competencias Claves para la Gestión del Conocimiento. Universidad \& Ciencia, 2, 38-50.

Martínez-Fernández, J. M., \& Esteva-Selma, M. A. E. (2007). Gestión integrada de cuencas costeras: Dinámica de los nutrientes en la Cuenca del mar Menor (sudeste de España). Revista de dinámica de Sistemas, 3, 2-23.

Martínez-Fierro, S., Biedma-Ferrer, J. M., \& Ruiz-Navarro, J. (2020). Impact of high-growth start-ups on entrepreneurial environment based on the level of national economic development. Business Strategy and the Environment, 29(3), 1007-1020. https://doi.org/10. 1002/bse. 2413

Mattingly, E. S., Kushev, T. N., Ahuja, M. K., \& Ma, D. (2016). Switch or persevere? The effects of experience and metacognition on persistence decisions. International Entrepreneurship and Management Journal, 12(4), 1233-1263. https://doi.org/10.1007/s11365-016-0391-x

McClelland, D. V. (1961). The achieving society. Washington, DC: Van Nostrand. https://doi.org/10.1037/14359-000

Mellalieu, S. D., Neil, R., \& Hanton, S. (2006). Self-confidence as a mediator of the relationship between competitive anxiety intensity and interpretation. Research Quarterly for Exercise and Sport, 77(2), 263-270. https://doi.org/10.1080/02701367.2006.10599359

Miralles, F., Giones, F., \& Riverola, C. (2016). Evaluating the impact of prior experience in entrepreneurial intention. International Entrepreneurship and Management Journal, 12(3), 791-813. https://doi.org/10.1007/ s11365-015-0365-4

Mitchelmore, S., \& Rowley, J. (2010). Entrepreneurial competencies: A literature review and development agenda. International Journal of Entrepreneurial Behavior \& Research, 16(2), 92-111. https://doi.org/10. 1108/13552551011026995

Moloi, K., \& Nkhahle-Rapita, M. (2014). The impact of fashion Entrepreneurs' traits on the success of fashion businesses in the Gauteng Province in South Africa. Mediterranean Journal of Social Sciences, 5(4), 78-86. https://doi.org/10.5901/mjss.2014.v5n4p78

Moneva, J., \& Ortas, E. (2009). Desarrollo sostenible e información corporativa. Economía industrial, Edición especial: Industria y medio ambiente: El reto de la sostenibilidad(371), 139-154.

Moneva, J. M., \& Ortas, E. (2010). Corporate environmental and financial performance: A multivariate approach. Industrial Management \& Data Sustems, 110(2), 193-210.

Müller, T., Schuberth, F., \& Henseler, J. (2018). PLS path modeling-A confirmatory approach to study tourism technology and tourist behavior. Journal of Hospitality and Tourism Technology, 20, 249-266. https:// doi.org/10.1108/JHTT-09-2017-0106

Musibah, A. S., \& Alfattani, W. S. B. W. Y. (2013). Impact of intellectual capital on corporate social responsibility evidence from Islamic banking sector in GCC. International Journal of Finance and Accounting, 2(6), 307-311.

Nabi, G., Holden, R., Harris, M., \& Gibson, S. (2008). Examining the entrepreneurial attitudes of US business students. Education and Training, 50(7), 568-581. https://doi.org/10.1108/00400910810909036

Nyarku, K. M., \& Ayekple, S. (2019). Influence of corporate social responsibility on non-financial performance. Social Responsibility Journal, 15(7), 910-923. https://doi.org/10.1108/SRJ-04-2017-0059

Olugbola, S. A. (2017). Exploring entrepreneurial readiness of youth and startup success components: Entrepreneurship training as a moderator. Journal of Innovation \& Knowledge, 2(3), 155-171. https://doi.org/ 10.1016/j.jik.2016.12.004

Omidi, F., \& Shafiee, M. M. (2018). The impact of corporate social responsibility on social performance, financial performance and customer reactions in the food industry. International Journal of Business 
Innovation and Research, 17(2), 249. https://doi.org/10.1504/IJBIR. 2018.094767

Pisano, G. P. (2017). Toward a prescriptive theory of dynamic capabilities: Connecting strategic choice, learning, and competition. Industrial and Corporate Change, 26(5), 747-762. https://doi.org/10.1093/icc/ dtx026

Porfírio, J. A., Mendes, T. C., \& Felício, J. A. (2018). From entrepreneurship potential in culture and creative industries to economic development: The situation of UK and southern European countries. International Entrepreneurship and Management Journal, 14(2), 329-343. https://doi. org/10.1007/s11365-018-0501-z

Porter, M. E., \& Kramer, M. R. (2011). The big Idea: Creating Shared Value. How reinvent capitalism and unleash a wave of innovation and growth. Harvard Business Review, 89(1-2), 62-77.

Potter, J. (2008). Entrepreneurship and higher education. OECD-local economic and employment development (LEED).

Rao, P., \& Holt, D. (2005). Do green supply chains lead to competitiveness and economic performance? International Journal of Operations \& Production Management, 25(9), 898-916. https://doi.org/10.1108/ 01443570510613956

Rashid, A., Asif, F. M. A., Krajnik, P., \& Nicolescu, C. M. (2013). Resource conservative manufacturing: An essential change in business and technology paradigm for sustainable manufacturing. Journal of Cleaner Production, 57, 166-177. https://doi.org/10.1016/j.jclepro.2013.06.012

Razafindrambinina, D., \& Kariodimedjo, D. (2011). Is company intellectual capital linked to corporate social responsibility disclosure? Findings from Indonesia. IBIMA Publishing, 2011(article ID 511442, 11 pages). https://doi.org/10.5171/2011.511442

Redington, I. (2005). Making CSR happen: The contribution of people management. London UK: The Chartered Institute of Personnel and Development (CIPD).

Reverte, C., Gómez-Melero, E., \& Cegarra-Navarro, J. G. (2016). The influence of corporate social responsibility practices on organizational performance: Evidence from eco-responsible Spanish firms. Journal of Cleaner Production, 112, 2870-2884. https://doi.org/10.1016/j. jclepro.2015.09.128

Ribeiro, D., \& Castrogiovanni, G. J. (2012). The impact of education, experience and inner circle advisors on SME performance: Insights from a study of public development centers. Small Business Economics, 38(3), 333-349.

Riveros, P. H., López, J. E. N., \& Martínez, P. A. (2004). La Diversificación desde la Teoría de Recursos y Capacidades. Cuadernos de Estudios Empresariales, 18, 87-104.

Rodríguez, L. C., \& Ríos-Osorio, L. A. (2016). Evaluacción de sostenibilidad con metodología GRI. Dimensión Empresarial, 14(2), 73-89. https://doi. org/10.15665/rde.v14i2.659

Rodríguez-Gulías, M. J., Sousa Gabriel, V. M., \& Rodeiro-Pazos, D. (2020). The effect of good governance on business creation: A multilevel approach. Revista de Economía Mundial, 54, 21-42. https://doi.org/10. 33776/rem.v0i54.3825

Ruvio, A., Rosenblatt, Z., \& Hertz-Lazarowitz, R. (2010). Entrepreneurial leadership vision in nonprofit vs. for-profit organizations. The Leadership Quarterly, 21(1), 144-158. https://doi.org/10.1016/j.leaqua.2009. 10.011

Salehzadeh, R., Khazaei Pool, J., Tabaeeian, R. A., Amani, M., \& Mortazavi, M. (2017). The impact of internal marketing and market orientation on performance: An empirical study in restaurant industry. Measuring Business Excellence, 21(4), 273-290. https://doi.org/10. 1108/MBE-02-2016-0009

Santos, G., Marques, C. S., \& Ferreira, J. J. M. (2018). What are the antecedents of women's entrepreneurial orientation? International Entrepreneurship and Management Journal, 14(4), 807-821. https://doi.org/ 10.1007/s11365-017-0481-4

Sarstedt, M., Ringle, C. M., \& Hair, J. F. (2017). Partial least squares structural equation modeling. In C. Homburg, M. Klarmann, \& A. Vomberg
(Eds.), Handbook of market research (pp. 1-40). Springer Nature Switzerland AG 2020: Springer International Publishing. https://doi.org/ 10.1007/978-3-319-05542-8_15-1

Sarstedt, M., Ringle, C. M., Smith, D., Reams, R., \& Hair, J. F. (2014). Partial least squares structural equation modeling (PLS-SEM): A useful tool for family business researchers. Journal of Family Business Strategy, 5 (1), 105-115. https://doi.org/10.1016/j.jfbs.2014.01.002

Sarwoko, E., Surachman, A., \& Hadiwidjojo, D. (2013). Entrepreneurial characteristics and competency as determinants of business performance in SMEs. IOSR Journal of Business and Management, 7(3), 31-38. https://doi.org/10.9790/487X-0733138

Schoemaker, P. J. H., Heaton, S., \& Teece, D. (2018). Innovation, dynamic capabilities, and leadership. California Management Review, 61(1), 15-42. https://doi.org/10.1177/0008125618790246

Schumpeter, J. (1934). Review of Robinson's Economics of Imperfect Competition. Journal of Political Economy, 42(2), 249-259.

Shabbir, A., \& di Gregorio, S. (1996). An examination of the relationship between women's personal goals and structural factors influencing their decision to start a business: The case of Pakistan (Vol. 11). https://doi.org/10.1016/S0883-9026(96)00034-1

Shane, S. (2000). Prior knowledge and the discovery of entrepreneurial opportunities. Organizacion Science, 11(4), 448-469. https://doi.org/ 10.1287/orsc.11.4.448.14602

Shepherd, D., \& Patzelt, H. (2010). The new field of sustainable entrepreneurship: Studying entrepreneurial action linking «what is to be sustained» with «what is to be developed». Entrepreneurship, Theory and Practise, 35, 137-163.

Simón-Moya, V., Revuelto-Taboada, L., \& Madina Lorza, A.F. (2012). La influencia de la formación, la experiencia y la motivación Para emprender en la supervivencia de las empresas de nueva creación. Estudios Gerenciales, 28 special edition, 237-262. https://doi.org/10. 18046/j.estger.2012.1487

Sørensen, J. B. (2007). Closure and exposure: Mechanisms in the intergenerational transmission of self-employment. In M. Ruef \& $M$. Lounsbury (Eds.), The sociology of entrepreneurship (Vol. 25) (pp. 83124). Bingley: Emerald Group Publishing Limited. https://doi.org/10. 1016/S0733-558X(06)25003-1

Stam, W., Woute, A., \& Elfring, T. (2014). Social capital of entrepreneurs and small firm performance: A meta-analysis of contextual and methodological moderators. Journal of Business Venturing, 29(1), 152-173. https://doi.org/10.1016/j.jbusvent.2013.01.002

St-Jean, É., Tremblay, M., Janssen, F., Baronet, J., Loué, C., \& Nafa, A. (2017). May business mentors act as opportunity brokers and enablers among university students? International Entrepreneurship and Management Journal, 13(1), 97-111. https://doi.org/10.1007/s11365-0160397-4

Suarez, L., \& Maldonado, J. (2018). La comunicación Como estrategia generadora de confianza en los emprendimientos. INNOVA Research Journal, 3(1), 95-107. https://doi.org/10.33890/innova.v3.n1. 2018.601

Szerb, L., Lafuente, E., Horváth, K., \& Páger, B. (2019). The relevance of quantity and quality entrepreneurship for regional performance: The moderating role of the entrepreneurial ecosystem. Regional Studies, 53 (9), 1308-1320. https://doi.org/10.1080/00343404.2018.1510481

Teece, D. J., Pisano, G., \& Shuen, A. (1997). Dynamic capabilities and strategic management. Strategic Management Journal, 18(7), 509-533. https://doi.org/10.1002/(SICI)1097-0266(199708)18:7<509::AIDSMJ882>3.0.CO;2-Z

Tharenou, P., Saks, A. M., \& Moore, C. (2007). A review and critique of research on training and organizational-level outcomes. Human Resource Management Review, 17(3), 251-273. https://doi.org/10. 1016/j.hrmr.2007.07.004

Urbano, D., Audretsch, D., Aparicio, S., \& Noguera, M. (2019). Does entrepreneurial activity matter for economic growth in developing countries? The Role of the Institutional Environment. International 
Entrepreneurship and Management Journal., 16, 1065-1099. https:// doi.org/10.1007/s11365-019-00621-5

Valenzuela Fernández, L., Jara-Bertin, M., \& Villegas Pineaur, F. (2015). Prácticas de responsabilidad social, reputación corporativa y desempeño financiero. Revista de Administração de Empresas, 55(3), 329-344. https://doi.org/10.1590/S0034-759020150308

Velasco, A. M., Pérez-Ruzafa, A., Martínez-Paz, J. M., \& Marcos, C. (2017). Servicios ecosistémicos y principales riesgos ambientales en una laguna costera (MarMenor, Murcia, SE España): La percepción pública. Journal for Nature Conservation, 43, 180-189. https://doi.org/10. 1016/j.jnc.2017.11.002

West, G., \& Noel, T. (2009). The impact of knowledge resources on new venture performance. Journal of Small Business Management, 47(1), 1-22. https://doi.org/10.1111/j.1540-627X.2008.00259.x

Weston, R., Lawler, M., Jarratt, D., Guia, J., Prats, L., Blasco, D., FerrerRoca, N., \& Mihalič, T. (2019). Research for TRAN committee-European tourism: Recent developments and future challenges. European Parliament, Policy Department for Structural and Cohesion Policies, Brussels, 104, 1-104.

Wilburn, K. M., \& Wilburn, R. (2011). Achieving social license to operate using stakeholder theory. Journal of Internacional Business Ethics, 4(2), 3-16.

Williams, N., \& Vorley, T. (2014). Economic resilience and entrepreneurship: Lessons from the Sheffield City region. Entrepreneurship and Regional Development, 26(3-4), 257-281. https://doi.org/10.1080/ 08985626.2014.894129

Yalcinkaya, G., Calantone, R. J., \& Griffith, D. A. (2007). An examination of exploration and exploitation capabilities: Implications for product innovation and market performance. Journal of International Marketing, 15 (4), 63-93. https://doi.org/10.1509/jimk.15.4.63

Yáñez-Araque, B., Hernández-Perlines, F., \& Moreno-Garcia, J. (2017). From training to organizational behavior: A mediation model through absorptive and innovative capacities. Frontiers in Psychology, 8, 1532. https://doi.org/10.3389/fpsyg.2017.01532

Yang, F., \& Zhang, H. (2018). The impact of customer orientation on new product development performance: The role of top management support. International Journal of Productivity and Performance Management, 67(3), 590-607. https://doi.org/10.1108/IJPPM-08-2016-0166

$\mathrm{Yi}, \mathrm{G}$. (2020). From green entrepreneurial intentions to green entrepreneurial behaviors: The role of university entrepreneurial support and external institutional support. The International Entrepreneurship and Management Journal. https://doi.org/10.1007/s11365-020-00649-y

Yunis, M., Tarhini, A., \& Kassar, A. (2018). The role of ICT and innovation in enhancing organizational performance: The catalysing effect of corporate entrepreneurship. Journal of Business Research, 88, 344-356. https://doi.org/10.1016/j.jbusres.2017.12.030

Zeng, J., \& Mackay, D. (2018). The influence of managerial attention on the deployment of dynamic capability: A case study of internet platform firms in China. Industrial and Corporate Change, 28(5), 1173-1192. https://doi.org/10.1093/icc/dty057

Zhu, L., Kara, O., \& Zhu, X. (2019). A comparative study of women entrepreneurship in transitional economies the case of China and Vietnam. Journal of Entrepreneurship in Emerging Economies, 11(1), 66-80. https://doi.org/10.1108/JEEE-04-2017-0027

How to cite this article: Teruel-Sánchez R, Briones-

Peñalver AJ, Bernal-Conesa JA, de Nieves-Nieto C. Influence of the entrepreneur's capacity in business performance. Bus Strat Env. 2021;1-15. https://doi.org/10.1002/bse.2757 